\title{
Research and Development on Authentic Assessment for Language Domain in Kartika Batu Kindergarten
}

\author{
Irena Agatha Simanjuntak ${ }^{1, *}$ Nurhenti Simatupang $^{2}$ \\ ${ }^{1}$ Postgraduate of Early Childhood Education Department, Malang State University, Malang, Indonesia \\ ${ }^{2}$ Teacher Education of Early Childhood Education Department, Surabaya State University, Surabaya, Indonesia \\ *Corresponding author. Email: irenasimanjuntak@gmail.com
}

\begin{abstract}
Educator and parents need clear information about how and what children learn. In Early Childhood Education (ECE), children's literacy abilities are often assessed by conventional tests to determine a child's 'readiness' for school. Readiness in terms of literacy consists of letter identification, phonemic awareness, letter-writing, and other functions related to language mechanics. Related to this, several studies conducted to find out a proper assessment for children's abilities. Thus, this study aims to produce a valid, practical, and effective conversation books and authentic assessment instruments that can be used by teachers in improving the assessment in learning process. This research used the Analysis, design, development, implementation and evaluation (ADDIE) model.
\end{abstract}

Keywords: Assessment instrument, language assessment, language domain

\section{INTRODUCTION}

Early childhood is often referred to as "golden age" in which at this time almost all the children's potential experiencing sensitive periods to grow and to develop quickly and greatly. In the context of ECE, education implies an effort to stimulate children consistently. ECE is increasingly recognized as an integral part of efforts to ensure that all children joining school. It is expected that children are ready to learn and it is a way to narrow the gaps before enrolling to primary school.

One of the supporting factors of ECE is professional educators. One of the competencies that professional educators need to master is assessment, that was in line with Novianti, Puspitasari, and Chairilsyah (2013). Conducting assessment and evaluation of learning process is a part of teacher's pedagogical competence that should be completed. Besides, it gives several benefits such as provide a clear view about children's development, physically and mentally, give feedbacks for teachers to develop the learning activities, and monitor learning activities, so that the children could achieve the learning objectives optimally. Assessment in education is necessary because it can be a tool for educators to improve the quality of education in the classroom. According to Bredekamp and Rosegrant (1992) assessment is the process of observing, recording, and documenting the work that children do and how they do it, as a basis for various educational decisions that affect children. Then, it is an integral part of curriculum and teaching. For early childhood programs, assessment has several different objectives; (1) to plan instructions for individuals and groups and to communicate with parents, (2) to identify children who might need special services or interventions, and (3) to evaluate how well the program achieves its objectives, and (4) to evaluate how well the program meets its objectives.

Based on the statement above, it can be concluded that the assessment provides useful information for teachers to successfully fulfill their responsibilities, such as; to support children's learning and development, to plan individuals and groups, and to communicate with parents. However, in ECE, assessment chosen to inform instructions for young children which used in daily routines, activities, and places. It also used to enter information from various sources that must be collected from time to time.

Language domain consists of three aspects that work independently and integrated. Firstly, receptive language, means that a child is being able to comprehend his/her native language which includes spoken words, written words, and also gestures. In early years, children start their communication by observing their peers and also adult. Secondly, expressive language which starts since the stage of babbling and gradually becomes sentences, and eventually written language. This is children's ability to express and to use language, including talking, writing, and reading. The last aspect is literacy. Literacy means what a child knows about expressive language and receptive language and to use it to their daily life. It includes knowledge, phonological awareness, alphabet knowledge, print concepts, and early writing.

In the classroom, children's literacy abilities are often assessed by tests that used to determine a child's 'readiness' for school. Readiness means that the children are able to know about letter identification, phonemic awareness, letter-writing, and other functions related to language systems. Through observations, collaboration meetings, interviews, classroom field notes and children's written texts, the researcher documented how three 
kindergarten teachers and their principals assessed children using assessment tools.

Assessments has washback effects on learning. According to Sarivan (2011, p. 195), the study showed the negative impact of assessment, selection, methodology policies on teachers and their students. The most common inadequacies resulted from puzzlement between the facilities and the objectives. Therefore, the assessment must be reliable and valid; in line with standards of child's and learning development and curriculum.

\section{METHOD}

\subsection{Models}

The development of this authentic instrument used the research and development ( $R$ \& D) model, because the outcome of the research was expected to construct an assessment instrument. According to Sugiyono (2016a, p. 297). R\&D is a method used in research to produce and test the effectiveness of products. The model was adapted from ADDIE design model and authentic assessment by Pierce \& O'malley (1992, p. 17). The model was chosen because it was appropriate for learning process in kindergarten that used authentic assessments. It aimed to develop assessment products. The selection of this model proposed to create a specific and detailed product in accordance with the research objectives.

The ADDIE model consists of 5 components that were interrelated and systematically structured. These five steps were very simple compared to other design models. Thus, it was easy to understand and to apply. According to Sugiyono (2016b), ADDIE research and development procedures consisted of five stages which include analysis, design, development, implementation and evaluation. The stages of\& authentic assessment design model, namely (Pierce \& O'Malley, 1992): (1) determination of the authentic assessments objectives, (2) preparation of product specifications, (3) professional development of authentic assessments, (4) collection of examples of authentic assessments, (5) adaptation of assessment, (6) testing of the assessment, (7) improvement of the assessment.

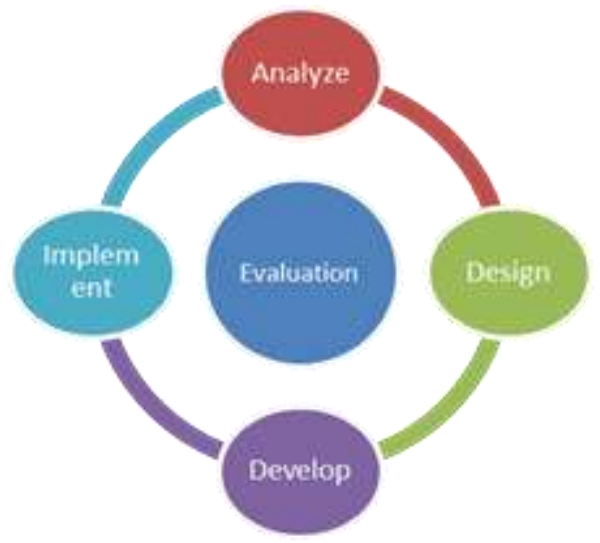

Figure 1 The ADDIE model

\subsection{Participant}

The participants in this research were experts and teachers who validated the instrument.

1) The experts consisted of an expert in early childhood educational, one in curriculum/assessment and one in linguistics. The education background of each expert was at least doctorate.

2) Teachers. They took a part since they have responsibilities for their center (learning center).

This development research aimed to produce an authentic assessment handbook on the language aspects of group $b$ children which was valid in terms of physical (book/ design), proper contents (material), practical, and effective in learning. The instruments were expert validation questionnaires, teacher response questionnaires, observation instruments, interview instruments, and study documentation in the form of student learning outcomes.

Table 1 Assessed aspects, instruments, observed data, and respondents

\begin{tabular}{|c|c|c|c|c|}
\hline Objectives & $\begin{array}{l}\text { Assessing } \\
\text { Aspects }\end{array}$ & Observed Data & Respondent & Instrument \\
\hline \multirow{3}{*}{$\begin{array}{l}\text { Test the validity, } \\
\text { practicality and } \\
\text { effectiveness of } \\
\text { the authentic } \\
\text { assessment } \\
\text { handbook on } \\
\text { children's } \\
\text { language domain }\end{array}$} & Validity & $\begin{array}{l}\text { Validity of the book's } \\
\text { content, layout and } \\
\text { grammar }\end{array}$ & Experts (3) & Validation's sheet \\
\hline & Practicality & $\begin{array}{l}\text { Teacher's responses to } \\
\text { the assessment book }\end{array}$ & Teachers (4) & $\begin{array}{l}\text { Interview and user's } \\
\text { validation sheet }\end{array}$ \\
\hline & Effectiveness & $\begin{array}{l}\text { Language formative } \\
\text { assessment to students }\end{array}$ & Students (20) & $\begin{array}{l}\text { Observation and } \\
\text { documentation }\end{array}$ \\
\hline
\end{tabular}




\section{RESULTS AND DISCUSSION}

The purpose of analyzing the data in this study was to determine the feasibility of the product development of authentic language assessment guidelines on children learning aged 5-6 years. The feasibility of authentic assessment guidelines can be seen based on the level of product validity, product practicality, and effectiveness of the product. The final stage was supposed to be completing content and editing organization before formatting. Proofreading to spelling and grammar was needed. The formula of effectiveness calculationin the research was as follows (Akbar, 2017).

Information

$$
V=\frac{T s e}{T s h} \times 100 \%
$$

$\mathrm{V}-\mathrm{ah}$ : expert judgement

Tse : reach total score

Table 2 Educational expert assessment results
Tsh : expected total score

$100 \%$ : constant numbers

\subsection{Expert Validation Results}

Expert validation was carried out to determine the appropriateness of the assessment instrument before being trialed to the field (the teacher). Validation aimed to determine the validity of the assessment instrument products developed by researchers. The results of expert validation were used as a reference in implementing improvements to the product design. The results of the validation were mapped out and collected using a data collection instrument in the form of a validation sheet. The validation data collection is aimed to early childhood education experts, assessment experts, and linguists.

\subsubsection{Results of early childhood education expert validation}

\begin{tabular}{|c|c|}
\hline Component & Rated aspect \\
\hline \multirow[t]{8}{*}{ Final Product } & The paper used is suitable \\
\hline & $\begin{array}{l}\text { The composition and arrangement of book elements (title, author, } \\
\text { illustration, logo, etc.) are proportional }\end{array}$ \\
\hline & Appearance of content according to the center of view \\
\hline & The separation between paragraphs is clear \\
\hline & Appearance of content according to the center of view \\
\hline & Print area and proportional margins \\
\hline & $\begin{array}{l}\text { Placement of titles, sub-headings, and page numbers does not } \\
\text { interfere with understanding }\end{array}$ \\
\hline & Systematic consistency of textbook writing \\
\hline \multirow[t]{4}{*}{ Illustration / Image / Photo } & Photos are able to illustrate the meanings of objects \\
\hline & Photo size is proportional and in accordance with its contents \\
\hline & Presentation of the overall photo match \\
\hline & Photos / illustrations used are interesting \\
\hline \multirow[t]{4}{*}{ Font } & The suitability and accuracy of the typeface \\
\hline & Proportional font size and easy to read \\
\hline & The use of letter variations is not excessive \\
\hline & Overall interesting guide book \\
\hline
\end{tabular}




\begin{tabular}{|l|l|}
\hline Material / Content & $\begin{array}{l}\text { The instruments presented are according to curriculum } \\
\text { and indicators }\end{array}$ \\
\cline { 2 - 2 } & $\begin{array}{l}\text { The points of assessment presented are appropriate to the level of } \\
\text { child development }\end{array}$ \\
\cline { 2 - 2 } & $\begin{array}{l}\text { The format of the instrument is made according to curriculum } \\
\text { demands }\end{array}$ \\
\hline
\end{tabular}

The table 4.1 shows the product validation was valid $(83 \%)$. Based on the evaluation criteria, the researcher concludes that there were still some important improvements and details that the researchers did not pay attention to, including; font use, table size, photo description and indicator writing. Therefore, researchers conducted revisions as a result of evaluations from expert validation.

\subsubsection{Result of assessment expert validation}

The content expert provided an assessment, in the form of a score, on the assessment handbook for teachers. It made for learning process of children aged 5 -6 years that has been developed. Besides, the expert gave critics and suggestions in the column provided. The results of it were shown in table 3 below.

Table 3 The results of the assessment by the material / content experts

\begin{tabular}{|c|c|}
\hline Component & Rated aspect \\
\hline \multirow[t]{4}{*}{ Relevance } & The material is delivered according to the stage of child development \\
\hline & $\begin{array}{l}\text { To the meaning of the material in accordance with the level } \\
\text { of child development }\end{array}$ \\
\hline & The assessment instrument is in accordance with the material / activity \\
\hline & Indicators of assessment according to the level of child development \\
\hline \multirow[t]{4}{*}{ Accuracy } & $\begin{array}{l}\text { Authentic assessment instruments about aspects of language in } \\
\text { accordance with the applicable curriculum }\end{array}$ \\
\hline & $\begin{array}{l}\text { The assessment instruments presented are in accordance with the } \\
\text { development of early childhood education }\end{array}$ \\
\hline & $\begin{array}{l}\text { Indicator of the assessment presented in accordance with the reality of } \\
\text { daily life / contextual }\end{array}$ \\
\hline & $\begin{array}{l}\text { The format of the instruments presented is thematically integrated so } \\
\text { that it is continuous with the learning process }\end{array}$ \\
\hline \multirow{4}{*}{$\begin{array}{l}\text { Practicality } \\
\text { of Assessment Instru } \\
\text { ments }\end{array}$} & The assessment instrument is clear and easy to use \\
\hline & The results of the assessment instruments are easily interpreted \\
\hline & $\begin{array}{l}\text { Presentation of the assessment instrument is clear and easy to } \\
\text { understand }\end{array}$ \\
\hline & Usage guidelines are clear and easy to understand \\
\hline \multirow[t]{3}{*}{ Language / Sentence } & The language used is formal and standard language \\
\hline & Appropriate sentence structure in the instrument \\
\hline & Appropriate use of terms in instruments \\
\hline
\end{tabular}


The spelling used refers to the general Indonesian spelling guidelines

Based on data from Table 4.2, the results of expert validation material to products developed were valid $(75 \%$ of 83 participants). Although the results showed that the product was valid, but researchers still needed to make revisions based on expert advice including; editorial writing related to assessment indicators, complementing other development indicators, and revising the language in order to become simple and communicative. Based on these criteria, it can be concluded that the authentic assessment handbook was valid and can be used in the learning of children aged 5-6 years in terms children's language domain.

Table 4 Teacher's validation

\subsubsection{User's validation}

The practicality analysis of the product development of the authentic language assessment guidelines was obtained from the teacher assessment questionnaire. It was carried out to find out how far the practicality of this authentic language assessment guideline can be implemented in learning. Field trials have been conducted generating data to assess the practicality and effectiveness of the language assessment handbook developed. The percentage of practicality scores based on the teacher's questionnaire responses during field trials was presented in table 4 below.

\begin{tabular}{|c|c|c|c|c|c|}
\hline \multirow[t]{2}{*}{ No. } & \multirow[t]{2}{*}{ Rated aspect } & \multicolumn{4}{|c|}{ Teacher Rating (Score) } \\
\hline & & 1 & 2 & 3 & 4 \\
\hline 1 & $\begin{array}{l}\text { The teacher requires a short time in the use } \\
\text { of instruments }\end{array}$ & 3 & 3 & 3 & 4 \\
\hline 2 & $\begin{array}{l}\text { The assessment instrument makes it easy for } \\
\text { teachers to carry out data collection on child } \\
\text { development }\end{array}$ & 4 & 3 & 4 & 4 \\
\hline 3 & $\begin{array}{l}\text { The teacher is easy to process data and } \\
\text { interpret the results of the assessment }\end{array}$ & 4 & 4 & 3 & 4 \\
\hline 4 & $\begin{array}{l}\text { Usage guidelines make it easy for teachers } \\
\text { to understand assessment instruments }\end{array}$ & 3 & 3 & 4 & 4 \\
\hline 5 & $\begin{array}{l}\text { Assessment techniques according to learning } \\
\text { needs }\end{array}$ & 4 & 4 & 4 & 4 \\
\hline 6 & Clarity of mapping assessment tasks & 3 & 4 & 3 & 3 \\
\hline 7 & Attractive book display & 4 & 4 & 4 & 3 \\
\hline 8 & Easy to use as an alternative assessment & 4 & 4 & 3 & 3 \\
\hline 9 & Use language that is easy to understand & 4 & 4 & 4 & 3 \\
\hline 10 & $\begin{array}{l}\text { Material or content according to the child's } \\
\text { needs }\end{array}$ & 4 & 4 & 4 & \\
\hline
\end{tabular}

Based on table 4, the percentage of the value of practicality based on questionnaire was $6 \%$ which means very practical. Apart from questionnaire data collection instruments, researchers conducted interviews with teachers to find out teacher opinions and ratings of the product being developed. Furthermore, the results of interviews were: (1) Assessment instruments in the guide were easy for teachers to develop and in accordance with the 2013 curriculum, (2) The format of the assessment was used according to the needs of children and teachers, (3)
The format of the assessment instruments can be used to conduct assessments on different aspects, (4) Assessment helped teachers to find the suitability of the material, the achievement of learning objectives, the meaningfulness of learning materials, and the effectiveness of learning methods. In conclusion, this assessment was suitable to assess the children's language domain, specifically children aged 5-6 years old (group B). 


\section{CONCLUSION}

The authentic assessment handbook has been revised by researchers for the perfection of the product based on expert advice. The revision of the authentic assessment manual was carried out after the first field trial. Based on the analysis of data and comments of teachers, it found that the practical value of 90 was $6 \%$. These results indicated that the product was very practical and effective. Even so, the researchers continue to make revisions, after the first field trial, to improve the product in the form of an authentic language assessment handbook in science learning developed based on teachers' suggestions.

\section{REFERENCES}

Akbar, S. (2017). Instrumen perangkat pembelajaran.

Bandung: Rosdakarya.

Bredekamp, S., \& Rosegrant, T. (1992). Guidelines for appropriate curriculum content and assessment. National Association for The Education of Young Children, 1(2), 9-27.

Novianti, R., Puspitasari, E., \& Chairilsyah, D. (2013). Pemetaan Kemampuan Guru Paud Dalam Melaksanakan Asesmen Perkembangan Anak Usia Dini di Kota Pekanbaru. Sorot, 8(1), 95-104.

Pierce, L. V., \& O'malley, J. M. (1992). Performance and portfolio assessment for language minority students. Program Information Guide Series, (9), 1-29.

Sarivan, L. (2011). The reflective teacher. Procedia Social and Behavioral Sciences, 11, 195-199. doi:https://doi.org/10.1016/j.sbspro.2011.01.060

Sugiyono. (2016a). Metode penelitian: Kuantitatif, kualitatif, dan R\&D. Bandung: Alfabeta.

Sugiyono. (2016b). Metode penelitian kualitatif, kuantitatif dan kombinasi (Mixed-methods). Bandung: Alfabeta. 